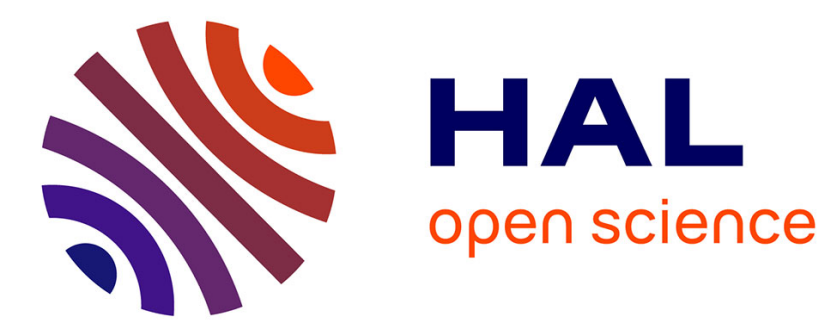

\title{
Experimental nerve anastomosis with the carbon dioxide laser
}

\author{
V. Travers, P. Lenz, J. Comtet, J. Margonari
}

\section{To cite this version:}

V. Travers, P. Lenz, J. Comtet, J. Margonari. Experimental nerve anastomosis with the carbon dioxide laser. Journal de Physique IV Proceedings, 1994, 04 (C4), pp.C4-249-C4-251. 10.1051/jp4:1994457 . jpa-00252720

\section{HAL Id: jpa-00252720 https://hal.science/jpa-00252720}

Submitted on 1 Jan 1994

HAL is a multi-disciplinary open access archive for the deposit and dissemination of scientific research documents, whether they are published or not. The documents may come from teaching and research institutions in France or abroad, or from public or private research centers.
L'archive ouverte pluridisciplinaire HAL, est destinée au dépôt et à la diffusion de documents scientifiques de niveau recherche, publiés ou non, émanant des établissements d'enseignement et de recherche français ou étrangers, des laboratoires publics ou privés. 


\title{
Experimental nerve anastomosis with the carbon dioxide laser
}

\author{
V. TRAVERS, P. LENZ* , J.J. COMTET and J. MARGONARI* \\ Institut de la Main, Clinique du Parc, 69006 Lyon, France \\ * INSERM U 281, 69424 Lyon, France
}

\section{INTRODUCTION}

The return of function following transection of the rat sciatic nerve has been assessed after repair by either standard microsurgery or by alternative techniques.

In the conventional technique using microsutures the inflammatory reaction around the sutures and the foreign body reaction are strong, inducing scarring and distortion at the site of anastomosis. Morever, with this technique the nerve is not totally and circumferentially coapted. This can lead to neuroma and leakage of neurotropic substances. Fibrin glue has been used for nerve grafts but the mechanical strength is not necessarily good and a local fibroblastic reaction is always present.

Laser suture, using a $\mathrm{CO} 2$ laser, has been performed in experimental studies.

Epineural fusion seemes to be satisfactory since no inflammatory reaction is observed. However, the tensile strength is not as good as with conventional sutures, particularly during the first week. Complications due to suture dehiscence may occur.

The aim of our study was to answer the following questions :

- What are the effects of laser irradiation on the endoneurium of a sutured nerve ?

- What is the local toxicity of the laser irradiation on a not transected nerve?

\section{MATERIALS METHODS :}

A carbon dioxide laser (S.A.T., Paris, France) was used with aproximately $50 \mathrm{~mW}$ output power.

The laser was rigidly fixed to the surgical microscope so that the focussed beam pointed to the spot in the middle of the visual field. A coaxial HeNe Laser beam visualized a spot. 
20 Wistar albino rats (250 to $400 \mathrm{~g}$ ) were anesthetized with intraperitoneal penthotal and prepared for sciatic nerve surgery. The rats were assigned to one of two groups, i.e. either nerve section and laser anastomosis (1), or laser irradiation without suture (2).

\section{Suture group :}

The section of the nerve was followed by two epineurial stay sutures using a ten zero Nylon monofilament. Then laser irradiation was applied on the circumference of the nerve, between the two stay sutures.

The achievement of epineurial welding was indicated by the site of anastomosis turning slightly brown.

The necessary duration of irradiation varied considerably (12 to $60 \mathrm{sec})$.

\section{Group without suture}

A circumferential irradiation of the nerve was performed, with exposure times roughly equivalent to what was required for suture ( 24 to $60 \mathrm{sec}$ ).

The rats were sacrificed at different time intervals : immediately, 1 week, 2 weeks, 3 weeks, or 4 weeks after the intervention. After H.P.S. fixation histologic examination was performed on longitudinal cuts.

In the group without suture, walking track analysis was used.

\section{RESULTS :}

\section{Suture group:}

Immediately after irradiation a good laser epineural fusion was generally obtained, with a good coaptation of the two parts of the nerve. Local disorganization in the longitudinal orientation of the fibers was observed at the suture site. A partial dehiscence between the two stay sutures occurred sometimes. 
One to two weeks after irradiation the longitudinal orientation of the fibers was still disturbed. However, epineural fusion was completed with good continuity.

Three to four weeks after irradiation, a progressive arrangement of the fibers was observed at the suture site, sometimes with a very good longitudinal continuity, sometimes with some remaining local disorganization.

\section{Group without suture :}

The walking track analysis showed a normal functional performance.

Visual inspection revealed peripheral lesions such as drying and curling of tissue, or moderate carbonaceus deposition without perforation, depending on the exposure time.

An immediate microscopic examination showed peripheral lesions due to thermal fusion, with epineural necrosis, but endoneural lesions were either absent or moderate. Progressive healing of the lesions was observed, and complete recovery after 4 weeks .

\section{CONCLUSION:}

- Irradiation of a nerve with a $50 \mathrm{~mW} \mathrm{CO} 2$ laser did not have any effect on walk performance in rats.

- Good epineural fusion and good continuity of the fibers at the suture site were observed after 4 weeks.

- Mechanical tensile strength seemed to be insufficient in the first week, indicating that laser anastomosis should not be performed without suture.

The laser treatment appears to provide complete fusion of the epineurium. This should make it possible to obtain better results in nerve regeneration, but further investigations are necessary. The principal advantage of laser treatment appears to be the obtainment of complete fusion of epineurium. 